\title{
Treatment of Antegrade Left Main Coronary Artery Dissection Due to A latrogenic Catheter Using the Reverse Crush Bifurcation Technique
}

\author{
İatrojenik Katetere Bağlı Antegrad Sol Ana Koroner Arter Diseksiyonunun Reverse \\ Crush Bifurkasyon Tekniği ile Tedavi Edilmesi
}

(D) Ahmet Öz, (D) Süleyman Çağan Efe, (D) Mehmet Sait Altıntaş, (D) Turgut Karabă̆, (D) Burak Ayça

University of Health Sciences Turkey, İstanbul Training and Research Hospital, Clinic of Cardiology, İstanbul, Turkey

\begin{abstract}
latrogenic left main coronary artery (LMCA) dissection is a rare but potentially life-threatening complication of invasive coronary procedures. The technique for managing LMCA dissection varies and depends on the patient's comorbidities and degree of hemodynamic stability. Here, we report the case of a 51-year-old patient with iatrogenic LMCA dissection who was successfully treated using the reverse crush bifurcation technique.
\end{abstract}

Keywords: latrogenic dissection, left main coronary artery, reverse crush bifurcation technique

\section{öZ}

İatrojenik sol ana koroner arter (LMCA) diseksiyonu, invaziv koroner prosedürlerin nadir ancak potansiyel olarak yaşamı tehdit edici bir komplikasyonudur. LMCA diseksiyonunu yönetme stratejisi değișkendir ve hastanın komorbiditelerine ve hemodinamik stabilite derecesine bağlıdır. Burada; 51 yașında erkek iatrojenik LMCA diseksiyonu olan hastanın reverse crush bifurkasyon tekniği ile bașarılı bir șekilde tedavi edildiği bir olgu sunulmuștur.

Anahtar Kelimeler: l̇atrojenik diseksiyon, sol ana koroner arter, reverse crush bifurkasyon tekniği

\section{Introduction}

Coronary angiography is widely used worldwide (1). The overall complication rate in diagnostic coronary angiography is very low. Despite the experience of advanced catheter technologies and physicians, stroke and dissection/occlusion of peripheral or coronary arteries still remain a major problem in cardiac catheterization (2). The left main coronary artery (LMCA) is a significant and rare complication. LMCA dissection may occur due to iatrogenic, spontaneous, or ascending aortic dissection complication (3). Iatrogenic LMCA dissection can be seen as antegrade or retrograde dissection (4). Here; a case of iatrogenically catheter-induced antegrade LMCA dissection and successfully treated using reverse crush bifurcation technique was presented.

\section{Case Report}

A 51-year-old male patient was evaluated in an outpatient clinic with a typical complaint of exertion dyspnea and angina that occurred with minimal exertion over the last 20 days. On physical examination, the heart sounds were rhythmic and no additional sound/murmur was heard. Other system examinations were normal. His resume included hyperlipidemia and smoking. He had no history of constant drug use. His pedigree had no obvious features. His electrocardiogram was in sinus rhythm. No change in segment ST-T was observed, and systolic function was normal in echocardiography (EF 60\%). The patient was admitted to the coronary intensive care unit with the diagnosis of unstabil angina pectoris. Blood tests showed fasting blood glucose: $101 \mathrm{mg} / \mathrm{dL}$, creatinine: $0.7 \mathrm{mg} / \mathrm{dL}$, low-density lipoprotein: $220 \mathrm{mg} / \mathrm{dL}$ and HbA1c: $5.5 \mathrm{mmoL} /$ moL. Selective coronary angiography was planned for the patient and written informed consent was obtained. In coronary angiography; There was plaque in the distal of the LMCA, subtotal stenosis in the osteal of the left anterior descending (LAD) artery and distal TIMI-3 flow. The circumflex (CX) artery was detected with plaques in the first poses, and the dissection line extending from the LMCA to the distal of the CX artery was observed in the caudal poses. The right coronary artery was found
Address for Correspondence/Yazıșma Adresi: Ahmet Öz MD, University of Health Sciences Turkey, İstanbul Training and Research Hospital, Clinic of Cardiology, İstanbul, Turkey

Phone: +90 5332075510 E-mail: drozahmet@gmail.com ORCID ID: orcid.org/0000-0003-0268-9641

Cite this article as/Atıf: : Öz A, Efe SÇ, Altıntaș MS, Karabağ T, Ayça B. Treatment of Antegrade Left Main Coronary Artery Dissection Due to A Iatrogenic Catheter Using the Reverse Crush Bifurcation Technique. İstanbul Med J 2020; 21(Suppl 1): 1-3.

(C) Copyright 2020 by the University of Health Sciences Turkey, Istanbul Training and Research Hospital/Istanbul Medical Journal published by Galenos Publishing House

(C) Telif Hakkı 2020 Sağlık Bilimleri Üniversitesi istanbul Ĕgitim ve Araştırma Hastanesi/Istanbul Tıp Dergisi, Galenos Yayınevi tarafından basılmıștır.
Received/Geliș Tarihi: 07.12.2019 Accepted/Kabul Tarihi: 06.01.2020 
with plaques (Figure 1). After the patient had severe angina during the coronary imaging process and monitoring ST depressions on the monitor, percutaneous coronary intervention $(\mathrm{PCI})$ was planned for the patient's lesions. The left system was cannulated with a 7-F EBU 3.75 guiding catheter. 8,000 units of heparin and intravenous tirofiban were administered. Soft wires were directed to the LAD artery and CX artery distal. LAD artery osteal lesion was predilated using a 2.0x15 $\mathrm{mm}$ balloon. Then, a 3.0x18 mm drug-eluting stent (DES) was implanted from the LMCA at $16 \mathrm{~atm}$ to the LAD artery osteal region, Proximal optimization technique was performed with a 4.0x9 mm non-compliant balloon. Soft wire was advanced distally by performing CX artery rewiring. Kissing dilatation was applied using LAD artery 3.0x15 mm and CX artery $2.0 \times 20 \mathrm{~mm}$ balloons. When $3.0 \times 33 \mathrm{~mm}$ DES could not be advanced to the $C X$ artery lesion, kissing dilatation was applied again using LAD

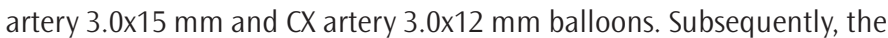
proximal 3.0x33 mm DES was implanted in the CX artery at $16 \mathrm{~atm}$, with the LMCA stent enclosed. Since dissection was limited in the distal of the stent and it did not disturb the distal flow, he was followed up medically. The stent was crushed with a 3.0x15 mm balloon, the proximal part of which was parked in the LAD artery. CX artery rewiring was done again and kissing dilatation was applied with 3.0x15 mm balloons. Due to dissection line monitoring in LMCA proximal, 4.5x9 mm bare metal stent was implanted at $16 \mathrm{~atm}$. The patient's angina complaints regressed, ST depression improved, and the procedure was terminated. After 4 days of follow-up in the coronary intensive care unit, the patient was discharged with acetyl salicylic acid $100 \mathrm{mg} 1 \times 1$, clopidogrel $75 \mathrm{mg}$ $1 \times 1$, metoprolol $50 \mathrm{mg} 1 \times 1$, ramipril $2.5 \mathrm{mg} 1 \times 1$, pantoprozole $40 \mathrm{mg}$ $1 \times 1$ and atorvastatin $40 \mathrm{mg} 1 \times 1$ and control coronary angiography was planned. In the control coronary angiography performed one month later; The LMCA stent was open, minimal dissection area the proximal stent, LAD artery stent open, CX artery stent open, dissection area distal to the stent that limited itself and did not disrupt the flow was detected (Figure 2). Since the patient did not have angina and exertional dyspnea, medical follow-up was decided.

\section{Discussion}

latrogenic LMCA dissection is a rare complication during coronary angiography or angioplasty. Incidence has been reported at

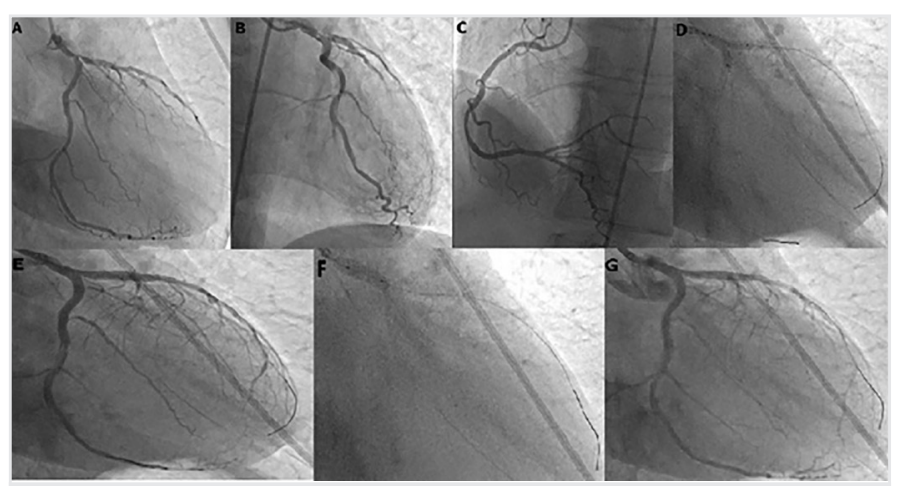

Figure 1. A: Subtotal stenosis in the left anterior descending artery osteal, B: Dissection extending from left main coronary artery to distal to circumflex artery, C: Right coronary artery plated, D: Kissing ballooning, E: dissection at proximal left main coronary artery, F: Left anterior descending artery proximal stent implantation, G: Successful reverse crush bifurcation stenting

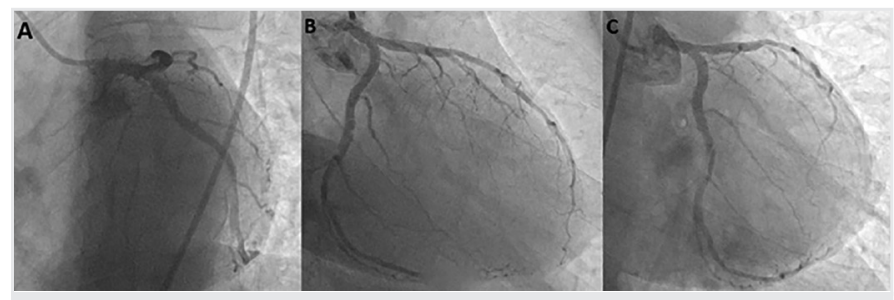

Figure 2. A, B: Open left main coronary artery stent, minimal dissection area proximal to stent, C: Circumflex artery stent is open; self-limiting dissection line distal to the stent

approximately $0.07 \%$ (5). Iatrogenic LMCA dissection risk factors may depend on the patient and the procedure. Patient-related risk factors can be listed as; coronary artery abnormalities, connective tissue disorders (Marfan's syndrome), atherosclerotic changes (LMCA stenosis), arterial hypertension, bicuspid aortic valve, aortic root calcification and age (6). Procedure-related risk factors include catheter manipulation, use of $>6 \mathrm{~F}$ catheters, stiff catheter tips, strong contrast agent injection, balloon dilation, and stenting $(7,8)$. Medical follow-up (if there is no hemodynamic disorder), $\mathrm{PCl}$ and coronary bypass operation are available as treatment. $\mathrm{PCl}$ is preferred in hemodynamically unstable patients in terms of time and technique (9). In an observational study involving 38 patients with iatrogenic LMCA dissection, 6 patients were treated conservatively, 14 patients were treated percutaneously, and 17 patients surgically. No difference was found between percutaneous intervention and surgery during the 5-year follow-up (5). If the hemodynamics of patients with iatrogenic LMCA dissection are not stable, it is very important for a positive result to be controlled quickly with percutaneous intervention. Our case was also successfully treated with reverse crush bifurcation technique due to unexpected catheterinduced LMCA dissection disrupting the patient's hemodynamics.

As a result, the best treatment strategy of choice in patients with iatrogenic LMCA dissection is immediate recognition of this complication, determination of the hemodynamic state of the patient and the need for surgery. Stenting strategy by percutaneous intervention is acceptable in hemodynamically unstable patients and should be carried out as soon as possible.

\section{Ethics}

Informed Consent: The patient and written informed consent was obtained.

Peer-review: Internally peer-reviewed.

Authorship Contributions: Surgical and Medical Practices - A.Ö., B.A.; Concept - A.Ö.; Design - A.Ö., B.A., T.K.; Data Collection or Processing S.Ç.E.; Literature Search - M.S.A., S.Ç.E.; Writing - A.Ö., T.K.

Conflict of Interest: No conflict of interest was declared by the authors. Financial Disclosure: The authors declared that this study received no financial support.

\section{References}

1. Noto TJ Jr, Johnson LW, Krone R, Weaver WF, Clark DA, Kramer JR Jr, et al. Cardiac catheterization 1990: a report of the Registry of the Society for Cardiac Angiography and Interventions (SCA\&I). Cathet Cardiovasc Diagn 1991; 24: 75-83. 
2. Ammann P, Brunner-La Rocca HP, Angehrn W, Roelli H, Sagmeister M, Rickli $\mathrm{H}$. Procedural complications following diagnostic coronary angiography are related to the operator's experience and the catheter size. Catheter Cardiovasc Interv 2003; 59: 13-8.

3. Awadalla H, Sabet S, El Sebaie A, Rosales O, Smalling R. Catheter-induced left main dissection incidence, predisposition and therapeutic strategies experience from two sides of the hemisphere. J Invasive Cardiol 2005; 17: 233-6.

4. Hokken RB, Foley D, van Domburg R, Serruys PW. Left main coronary artery dissection during percutaneous coronary intervention treated by stenting. Neth Heart J 2002; 10: 395-8.

5. Eshtehardi P, Adorjan P, Togni M, Tevaearai H, Vogel R, Seiler C, et al. latrogenic left main coronary artery dissection: incidence, classification, management, and long-term follow-up. Am Heart J 2010; 159: 1147-53.
6. Awadalla H, Sabet S, El Sebaie A, Rosales O, Smalling R. Catheter induced left main dissection incidence, predisposition and therapeutic strategies experience from two sides of the hemisphere. J Invasive Cardiol 2005; 17: 233-6.

7. Kovac JD, de Bono DP. Cardiac catheter complications related to left main stem disease. Heart 1996; 76: 76-8.

8. Boyle AJ, Chan M, Dib J, Resar J. Catheter-induced coronary artery dissection: risk factors, prevention and management. J Invasive Cardiol 2006; 18: 500-3.

9. Cheng $\mathrm{Cl}$, Wu CJ, Hsieh YK, Chen YH, Chen CJ, Chen SM, et al. Percutaneous coronary intervention for iatrogenic left main coronary artery dissection. Int J Cardiol 2008; 126: 177-82. 